\title{
EFFECT OF RIPENING STAGE AT HARVEST, COLD STORAGE, AND SIMULATED MARKETING CONDITIONS ON QUALITY AND ANTIOXIDANT ACTIVITY OF PEACH FRUIT
}

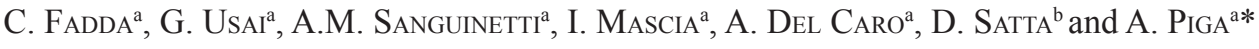 \\ aDipartimento di Agraria, Università degli Studi di Sassari, Viale Italia 39/A, 07100 Sassari. Italy \\ ${ }^{\mathrm{b}}$ AGRIS Sardegna, Dipartimento per la Ricerca nell'Arboricoltura, Viale Mameli 126d, 09123 Cagliari. Italy
}

(Received: 23 May 2015; accepted: 20 July 2015)

The influence of storage time on different quality parameters and in vitro antioxidant activity of peaches cv. Elegant Lady harvested at two ripening stages (immature and commercial mature) and stored under cold and marketing conditions were assessed. Destructive (physical-chemical properties, antioxidant activity, and firmness) and nondestructive parameters (colour and index of absorbance difference, $\mathrm{I}_{\mathrm{AD}}$ ) were assessed.

Storage and ripening stage influenced firmness, colour, and antioxidant activity. Firmness decreased significantly during cold and marketing storage, and skin colour parameters, $a^{*}$ and $b^{*}$, underwent a deepening of the red hue, while $\mathrm{I}_{\mathrm{AD}}$ values fully justified differences in colour over storage time and ripening stage. The antioxidant activity increased during storage, although polyphenols and ascorbic acid contents remained constant, and was higher in commercial mature fruit than immature peaches, that revealed a ratio of total sugars/total acids more equilibrated.

Keywords: antioxidant activity, fruit quality, shelf life, texture

Significant contributions of healthy phytochemicals are found in fresh fruit of Prunus species (McCune et al., 2010). Among Prunus, peaches have moderate amounts of carotenoids and polyphenols, but their higher consumption, with respect to the other Prunus species, contributes effectively to the daily intake of health promoting compounds (VICENTE et al., 2011).

Harvesting at an immature stage is a common commercial practice to extend the shelf life of peaches, while fruit picked at physiological maturity have a very short market life (INFANTE, 2012). So far, matching consumer satisfaction with extended shelf life has been a scarcely achieved goal. Recently, researchers focused their interest in developing nondestructive techniques to achieve online monitoring of fruit ripening stages. Among them, the most promising tool appears to be the use of visible/near infrared (vis/NIR) spectroscopy and in particular the Index of Absorbance Difference $\left(\mathrm{I}_{\mathrm{AD}}\right)$ (BONORA et al., 2013) that correlates very well with the flesh chlorophyll- $\alpha$ content and to ethylene production during fruit ripening (ZIOSI et al., 2008). Literature dealing with changes in quality parameters refers to peaches being stored at cold (CS) or under marketing conditions (MS) (DI VAIO et al., 2008; DAGAR et al., 2012), while, to our knowledge, the effects of storage under MS after CS on the quality parameters have not been considered.

\footnotetext{
All the authors contributed equally to this work.

* To whom correspondence should be addressed.

Phone: +39-079-229272; fax: +39-079-229272; e-mail: pigaa@uniss.it
} 
The changes in quality parameters and in vitro antioxidant activity (AA) of peach fruit subjected both to CS and subsequent MS were investigated, in order to find the best parameters explaining the evolution of ripening of fruit harvested at the commercial mature (CM) and immature (I) stages, as well as to see quality differences between fruit of the two ripening stages.

\section{Materials and methods}

\subsection{Fruit material, selection of ripening stage and storage conditions}

Peach fruit (Prunus persica L.) cv. 'Elegant lady' (sensitive to frost) were harvested from a farm located in southern Sardinia (Italy) and transported to the laboratory within two hours in a refrigerated car. Randomly picked fruit where assessed for their ripening stage with the DA-meter (TR Turoni, Forli, Italy) and expressed as $\mathrm{I}_{\mathrm{AD}}$. To select fruit at the $\mathrm{CM}$ and I stages, ethylene production of 50 randomly selected fruit was assessed with a HP 5890 gas chromatograph (Hewlett Packard, Palo Alto, CA, USA) as described by Zıosi and co-workers (2008). Fruit at the CM stage had a $\mathrm{I}_{\mathrm{AD}}$ from 0.7 to 0.9 , peaches at the I stage had a $\mathrm{I}_{\mathrm{AD}}$ from 1.1 to 1.3 . In particular I fruit showed an ethylene production close to 0.6 nanolitre per litre per hour per gram $\left(\mathrm{nl} \mathrm{l}^{-1} \mathrm{~h}^{-1} \mathrm{~g}^{-1}\right)$ of fresh weight, while CM fruit registered a value of $1.8 \mathrm{nl} \mathrm{l}^{-1} \mathrm{~h}^{-1} \mathrm{~g}^{-1}$ of fresh weight. Fruit were cold stored for 3 weeks at $6{ }^{\circ} \mathrm{C}$ and $90-95 \%$ relative humidity. After each week of CS, 90 fruit were transferred to $20^{\circ} \mathrm{C}$ and $70 \%$ relative humidity for 3 days to simulate MS.

\subsection{Fruit weight loss, colour, texture, evolution of $I_{\mathrm{AD}}$ and visual assessment of moulds and} defects

Thirty fruit were used to determine weight loss (WL), peel colour and, $\mathrm{I}_{\mathrm{AD}}$, and other 30 fruit were used for texture analysis. After colour determination, fruit were used for visual assessment. WL (\%) was computed on previously weighted fruit.

Colour and $\mathrm{I}_{\mathrm{AD}}$ evolution were assessed on the two opposite sides of the fruit. Colour was measured with a tristimulus colorimeter (Chromameter-2 Reflectance, Minolta, Osaka, Japan) as $L, a^{*}, b^{*}$ CIELAB parameters and hue angle $\left(\tan ^{-1} b^{*} / a^{*}\right)$ and Chroma $\left(a^{2}+b^{2}\right)^{0.5}$ were calculated. The evolution of $\mathrm{I}_{\mathrm{AD}}$ was followed with the DA-Meter, and calculated as absorbance difference between 670 and $720 \mathrm{~nm}$ wavelengths.

CI was evaluated as mealiness, internal browning, and internal reddening of the flesh and rated using a $0-3$ subjective scale, where $0=$ none, $1=$ slight, $2=$ moderate, and $3=$ severe injury.

Firmness was determined with a texture analyser (mod. TA.XT plus, Stable Microsystems, Surrey, UK). A puncture test was performed on the equatorial zone of 15 fruit with a $6 \mathrm{~mm}$ diameter cylinder probe (P6). Three indexes were selected: the peach peel break force (yield point) as the maximum force reached during both tests; the hardness of the peel and the flesh, the first as the area calculated starting from the starting point to yield point, the second as the area after the peel rupture; gradient or stiffness calculated from the start of the reading up to the yield point.

Mould incidence was expressed as percentage of rotten fruit caused by various fungi. 


\subsection{Chemical analysis}

Chemical analyses of fruit were performed by homogenising triplicates of 10 fruit with a commercial blender. Titratable acidity was determined by titrating $10 \mathrm{ml}$ of juice diluted to $50 \mathrm{ml}$ with distilled water by using $0.1 \mathrm{~N} \mathrm{NaOH}$ up to $\mathrm{pH} 8.1$ (\% of malic acid). The soluble solids content was measured by a digital refractometer (PR-101, Atago, Japan). Water content and dry matter (\%) were determined in a vacuum oven for $22 \mathrm{~h}$ at $70{ }^{\circ} \mathrm{C}$.

\subsection{HPLC analysis of organic acids and sugars}

Organic acids and sugars were extracted from fruit homogenate and analysed as reported by ORAZEM and co-workers (2011) with a HPLC Agilent 1100 Series (Agilent Technologies, Palo Alto, CA, USA). Organic acids were detected with an ultraviolet UV detector (G1315B, Agilent Technologies, Palo Alto, CA, USA) set at $210 \mathrm{~nm}$ after separation with a Rezex ROA organic acid $\mathrm{H}+(8 \%)$ column $(300 \times 7.8 \mathrm{~mm}$, Phenomenex, Torrance, CA) kept at room temperature. The elution solvent was $0.4 \mathrm{mM}$ sulphuric acid diluted with double-distilled

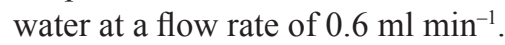

Individual sugars were detected with a refractive index (RI) detector (Model G1362A, Agilent Technologies, Palo Alto, CA, USA) following separation with a Rezex RCM monosaccharide column $\left(300 \times 7.8 \mathrm{~mm}\right.$; Phenomenex, Torrance, CA) kept at $65{ }^{\circ} \mathrm{C}$. The mobile phase was twice-distilled water at a flow rate of $0.6 \mathrm{ml} \mathrm{min}$.

Peaks of organic acids and sugars were identified by comparing retention times with those of standards and quantification was carried out using the same external standards. The total acids content (TA) and total sugars (TS) content were also computed.

\subsection{Spectrophotometric analysis of total polyphenols and antioxidant activity determination}

Total polyphenols (TP) were extracted from the whole fruit as reported by TOMAS-BARBERAN and co-workers (2001) and analysed as described by Singleton and Rossi (1965). The AA was evaluated using the free radical 2,2-diphenyl-1-picrylhydrazyl (DPPH·) (PIGA et al., 2003).

\subsection{Statistical analysis}

Data were evaluated by a two factor completely randomized factorial design, using Statistica 6.0 for Windows. Storage period and ripening stage were chosen as factors. The Tukey's test for $\mathrm{P} \leq 0.05,0.01$, and 0.001 was used when appropriate.

\section{Results and discussion}

\subsection{Chemical parameters, polyphenols and antioxidant activity, weight loss}

The ripening stage affected significantly only the AA, while storage time had some influences on $\mathrm{pH}$ and TS (Table 1). The variability in values of chemical parameters depends mainly on the position on the canopy (top and bottom) and row orientation of trees, thus we picked fruit at random on the tree to minimize variability. Storage time and ripening stage did not affect the TP, probably by a concomitant increase and decrease of TP. These results explain the fact that, although TP did not change over storage time, there was a significant increase in AA that 
was almost tripled after 21 days of CS and 3 days of MS. Moreover, ascorbic acid content, which is partially responsible for the AA, was influenced neither by storage nor by ripening stage, thus strengthening what previously reported. The constancy of ascorbic acid may be explained considering the balancing effect between the increase in content before full maturity and the decrease due to storage as reported by DALLA VALLE and co-workers (2007). Only TS changed at the end of MS following 14 days of CS.

Table 1. Influence of storage time and ripening stage on $\mathrm{pH}$, contents of total acids (TA), total polyphenols (TP), antioxidant activity (AA) and weight loss (WL) of peach fruit

\begin{tabular}{|c|c|c|c|c|c|c|c|}
\hline Source & $\mathrm{pH}$ & $\begin{array}{c}\text { TA } \\
(\mathrm{g} \text { malic } \\
\text { acid } / 100 \mathrm{~g} \\
\mathrm{dm})\end{array}$ & $\begin{array}{c}\text { SSC } \\
\left({ }^{\circ} \text { Brix }\right)\end{array}$ & $\begin{array}{c}\text { TP } \\
\text { (mg gallic } \\
\text { acid/100 g } \\
\text { dm) }\end{array}$ & $\begin{array}{c}\mathrm{AA} \\
\left(-\mathrm{OD}^{-3} /\right. \\
\min \\
\mathrm{g} \mathrm{dm})\end{array}$ & $\begin{array}{l}\text { Ascorbic } \\
\text { acid } \\
(\mathrm{g} / 100 \mathrm{~g} \\
\mathrm{dm})\end{array}$ & $\begin{array}{l}\text { WL } \\
(\%)\end{array}$ \\
\hline \multicolumn{8}{|c|}{ Storage time (days) } \\
\hline 0 & $4.4 \mathrm{bc}$ & $2.82 \mathrm{a}$ & $13.7 b$ & $255 \mathrm{a}$ & $1.93 \mathrm{e}$ & $0.153 \mathrm{a}$ & $0.00 \mathrm{f}$ \\
\hline $0+3$ & $4.3 \mathrm{c}$ & $2.79 \mathrm{a}$ & $13.9 \mathrm{ab}$ & $252 \mathrm{a}$ & $2.27 \mathrm{de}$ & $0.154 \mathrm{a}$ & $3.14 \mathrm{de}$ \\
\hline 7 & $4.5 \mathrm{ab}$ & $2.40 \mathrm{a}$ & $14.5 \mathrm{ab}$ & $254 \mathrm{a}$ & $2.62 \mathrm{de}$ & $0.165 \mathrm{a}$ & $1.60 \mathrm{ef}$ \\
\hline $7+3$ & $4.4 \mathrm{bc}$ & $2.51 \mathrm{a}$ & $15.0 \mathrm{ab}$ & $267 \mathrm{a}$ & $3.42 \mathrm{bcd}$ & $0.186 \mathrm{a}$ & $5.45 \mathrm{bc}$ \\
\hline 14 & $4.5 \mathrm{ab}$ & $2.56 \mathrm{a}$ & $13.4 \mathrm{~b}$ & $229 a$ & $3.08 \mathrm{cde}$ & $0.150 \mathrm{a}$ & $4.28 \mathrm{~cd}$ \\
\hline $14+3$ & $4.4 \mathrm{bc}$ & $2.36 \mathrm{a}$ & $15.7 \mathrm{a}$ & $270 \mathrm{a}$ & $4.15 \mathrm{abc}$ & $0.181 \mathrm{a}$ & $7.38 b$ \\
\hline 21 & $4.6 \mathrm{a}$ & $2.61 \mathrm{a}$ & $13.9 \mathrm{ab}$ & $244 \mathrm{a}$ & $4.67 \mathrm{ab}$ & $0.181 \mathrm{a}$ & $4.96 \mathrm{~cd}$ \\
\hline $21+3$ & $4.5 \mathrm{ab}$ & $2.51 \mathrm{a}$ & $14.3 \mathrm{ab}$ & $234 \mathrm{a}$ & $5.42 \mathrm{a}$ & $0.188 \mathrm{a}$ & $11.69 \mathrm{a}$ \\
\hline Significance & $* * *$ & ns & $*$ & ns & $* * *$ & ns & $* * *$ \\
\hline \multicolumn{8}{|c|}{ Ripening stage (IAD) } \\
\hline $\mathrm{CM}$ & $4.5 \mathrm{a}$ & $2.51 \mathrm{a}$ & $14.5 \mathrm{a}$ & $260 \mathrm{a}$ & $3.99 a$ & $0.166 a$ & $4.90 \mathrm{a}$ \\
\hline I & $4.4 \mathrm{a}$ & $2.62 \mathrm{a}$ & $14.1 \mathrm{a}$ & $241 \mathrm{a}$ & $2.90 \mathrm{~b}$ & $0.173 a$ & $4.72 \mathrm{a}$ \\
\hline Significance & ns & ns & ns & ns & $* * *$ & ns & ns \\
\hline
\end{tabular}

Data followed by different letters for each source and column are significantly different by Tukey's test.

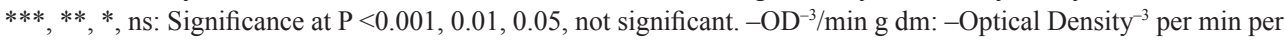
gram per dry matter

WL increased with storage time, especially when transferring fruit from CS to MS, while ripening stage had no effects.

\subsection{Changes in organic acids and sugars contents}

We found two major acids, malic and citric, and two minor ones, shikimic and fumaric, as well as ascorbic acid (Table 2). Citric and fumaric acid decreased only at 21 and 14 days of $\mathrm{CS}$, respectively. Citric and shikimic acid were significantly higher in I peaches, with respect to $\mathrm{CM}$ fruit, which revealed a higher content in fumaric acid. However, citric acid content in I peaches was higher at harvest time and after the first week of CS, then became similar to $\mathrm{CM}$ fruit, while content of shikimic acid was always higher in I peaches than CM ones. The $\mathrm{TA}$, however, due to the predominant contribution of malic acid, was not significantly affected by storage time or by ripening stage. 
Table 2. Influence of storage time and ripening stage on contents of organic acids of peach fruit

\begin{tabular}{|c|c|c|c|c|c|}
\hline Source & $\begin{array}{l}\text { Malic acid } \\
(\mathrm{g} / 100 \mathrm{~g} \mathrm{dm})\end{array}$ & $\begin{array}{c}\text { Citric acid } \\
(\mathrm{g} / 100 \mathrm{~g} \mathrm{dm})\end{array}$ & $\begin{array}{l}\text { Shikimic acid } \\
(\mathrm{mg} / 100 \mathrm{~g} \mathrm{dm})\end{array}$ & $\begin{array}{l}\text { Fumaric acid } \\
(\mathrm{mg} / 100 \mathrm{~g} \mathrm{dm})\end{array}$ & $\begin{array}{c}\text { TA } \\
(\mathrm{g} / 100 \mathrm{~g} \mathrm{dm})\end{array}$ \\
\hline \multicolumn{6}{|c|}{ Storage time (days) } \\
\hline 0 & $4.6 \mathrm{a}$ & $1.9 \mathrm{ab}$ & $29.1 \mathrm{a}$ & $12.7 \mathrm{ab}$ & $6.6 \mathrm{a}$ \\
\hline $0+3$ & $3.8 \mathrm{a}$ & $2.2 \mathrm{a}$ & $21.9 \mathrm{a}$ & $11.4 \mathrm{abc}$ & $6.1 \mathrm{a}$ \\
\hline 7 & $4.3 \mathrm{a}$ & $1.5 \mathrm{ab}$ & $25.4 \mathrm{a}$ & $13.0 \mathrm{a}$ & $5.9 \mathrm{a}$ \\
\hline $7+3$ & $4.8 \mathrm{a}$ & $2.2 \mathrm{a}$ & $27.8 \mathrm{a}$ & $9.1 \mathrm{abc}$ & $7.1 \mathrm{a}$ \\
\hline 14 & $3.8 \mathrm{a}$ & $1.5 \mathrm{ab}$ & $21.9 \mathrm{a}$ & $6.4 \mathrm{c}$ & $5.3 \mathrm{a}$ \\
\hline $14+3$ & $4.5 \mathrm{a}$ & $2.0 \mathrm{ab}$ & $26.0 \mathrm{a}$ & $6.3 \mathrm{c}$ & $6.5 \mathrm{a}$ \\
\hline 21 & $3.9 \mathrm{a}$ & $1.2 \mathrm{~b}$ & $23.2 \mathrm{a}$ & $7.4 \mathrm{abc}$ & $5.1 \mathrm{a}$ \\
\hline $21+3$ & $4.1 \mathrm{a}$ & $2.0 \mathrm{ab}$ & $24.3 \mathrm{a}$ & $6.9 \mathrm{bc}$ & $6.2 \mathrm{a}$ \\
\hline Significance & ns & $*$ & ns & $* *$ & ns \\
\hline \multicolumn{6}{|c|}{ Ripening stage (IAD) } \\
\hline $\mathrm{CM}$ & $4.2 \mathrm{a}$ & $1.7 \mathrm{~b}$ & $21.4 b$ & $10.2 \mathrm{a}$ & $5.9 \mathrm{a}$ \\
\hline I & $4.2 \mathrm{a}$ & $2.0 \mathrm{a}$ & $28.5 \mathrm{a}$ & $8.1 \mathrm{~b}$ & $6.2 \mathrm{a}$ \\
\hline Significance & ns & $*$ & $* * *$ & $*$ & ns \\
\hline
\end{tabular}

Data followed by different letters for each source and column are significantly different by Tukey's test. $* * *, * *, *$, ns: Significance at $\mathrm{P}<0.001,0.01,0.05$, not significant

Sugars detected were sucrose, glucose, fructose, and sorbitol (Table 3). Fructose increased, while sorbitol decreased, as reported by ROBERTSON and co-workers (1990). Storage time decreased the glucose/fructose ratio. The ripening stage affected significantly the content of sucrose and sorbitol that were lower in I fruit, which also evidenced lower sucrose/glucose and glucose/fructose ratios compared to CM peaches. The lower content of some sugars in I fruit resulted in lower TS, if compared to CM peaches, while storage time did not influence this parameter.

The ratio between TS and TA is a good indicator of the flavour of peaches. The higher the ratio, the sweeter the fruit are, while a lower ratio confers an unpleasant flavour. TS to TA ratios ranged from 8.69 to 10.45 along storage. A significantly lower ratio was found for I peaches than CM fruit. The optimal ratio for a balanced flavour has been reported to be between 7.8 and 8.5 (BASSI \& SeLLI, 1990), thus I peaches revealed a mean ratio very close to optimal. All acids and sugars did not change when transferring fruit form CS to MS, with the exception of sorbitol. 
Table 3. Influence of storage time and ripening stage on individual and total sugars contents of peach fruit

\begin{tabular}{|c|c|c|c|c|c|c|c|c|}
\hline \multirow[t]{2}{*}{ Source } & Sucrose & Glucose & Fructose & Sorbitol & \multirow{2}{*}{$\begin{array}{l}\text { Sucrose/ } \\
\text { glucose }\end{array}$} & \multirow{2}{*}{$\begin{array}{l}\text { Glucose/ } \\
\text { fructose }\end{array}$} & \multirow{2}{*}{$\begin{array}{c}\mathrm{TS} \\
\mathrm{g} / 100 \mathrm{~g} \\
\mathrm{dm}\end{array}$} & \multirow[t]{2}{*}{ TS/TA } \\
\hline & \multicolumn{4}{|c|}{$\mathrm{g} / 100 \mathrm{~g} \mathrm{dm}$} & & & & \\
\hline \multicolumn{9}{|c|}{ Storage time (days) } \\
\hline 0 & $35.9 \mathrm{a}$ & $10.6 \mathrm{a}$ & $8.9 \mathrm{c}$ & $6.2 \mathrm{a}$ & $3.4 \mathrm{a}$ & $1.2 \mathrm{a}$ & $61.7 \mathrm{a}$ & $9.3 \mathrm{a}$ \\
\hline $0+3$ & $33.1 \mathrm{a}$ & $10.0 \mathrm{a}$ & $8.8 \mathrm{c}$ & $3.8 \mathrm{bc}$ & $3.3 \mathrm{a}$ & $1.1 \mathrm{ab}$ & $55.6 \mathrm{a}$ & $9.1 \mathrm{a}$ \\
\hline 7 & $34.8 \mathrm{a}$ & $11.1 \mathrm{a}$ & $9.5 \mathrm{bc}$ & $5.9 \mathrm{a}$ & $3.1 \mathrm{a}$ & $1.1 \mathrm{ab}$ & $61.3 \mathrm{a}$ & $10.4 \mathrm{a}$ \\
\hline $7+3$ & $37.9 \mathrm{a}$ & $11.4 \mathrm{a}$ & $9.9 \mathrm{abc}$ & $2.4 \mathrm{c}$ & $3.4 \mathrm{a}$ & $1.1 \mathrm{ab}$ & $61.4 \mathrm{a}$ & $8.7 \mathrm{a}$ \\
\hline 14 & $32.7 \mathrm{a}$ & $10.0 \mathrm{a}$ & $8.9 \mathrm{c}$ & $3.6 \mathrm{bc}$ & $3.2 \mathrm{a}$ & $1.1 \mathrm{ab}$ & $55.1 \mathrm{a}$ & $10.4 \mathrm{a}$ \\
\hline $14+3$ & $33.5 \mathrm{a}$ & $10.5 \mathrm{a}$ & $9.8 \mathrm{abc}$ & $3.4 \mathrm{bc}$ & $3.2 \mathrm{a}$ & $1.0 \mathrm{~b}$ & $56.9 \mathrm{a}$ & $8.7 \mathrm{a}$ \\
\hline 21 & $37.9 \mathrm{a}$ & $11.7 \mathrm{a}$ & $10.9 \mathrm{a}$ & $5.1 \mathrm{ab}$ & $3.4 \mathrm{a}$ & $1.0 \mathrm{~b}$ & $65.7 \mathrm{a}$ & $12.9 \mathrm{a}$ \\
\hline $21+3$ & $38.4 \mathrm{a}$ & $11.4 \mathrm{a}$ & $10.6 \mathrm{ab}$ & $3.0 \mathrm{c}$ & $3.4 \mathrm{a}$ & $1.0 \mathrm{~b}$ & $62.8 \mathrm{a}$ & $10.2 \mathrm{a}$ \\
\hline $\begin{array}{l}\text { Signifi- } \\
\text { cance }\end{array}$ & $\mathrm{ns}$ & ns & $*$ & $* * *$ & $\mathrm{~ns}$ & $* *$ & ns & ns \\
\hline \multicolumn{9}{|c|}{ Ripening stage $\left(\mathrm{I}_{\mathrm{AD}}\right)$} \\
\hline $\mathrm{CM}$ & $40.3 \mathrm{a}$ & $10.9 \mathrm{a}$ & $9.5 \mathrm{a}$ & $4.6 \mathrm{a}$ & $3.7 \mathrm{a}$ & $1.1 \mathrm{a}$ & $65.2 \mathrm{a}$ & $11.0 \mathrm{a}$ \\
\hline I & $30.8 b$ & $10.8 \mathrm{a}$ & $9.9 \mathrm{a}$ & $3.8 \mathrm{~b}$ & $2.9 \mathrm{~b}$ & $1.0 \mathrm{~b}$ & $55.0 \mathrm{~b}$ & $8.8 \mathrm{~b}$ \\
\hline $\begin{array}{l}\text { Signifi- } \\
\text { cance }\end{array}$ & $* * *$ & ns & ns & $* *$ & $* * *$ & $* *$ & $* * *$ & $* *$ \\
\hline
\end{tabular}

Data followed by different letters for each source of variation and column are significantly different by Tukey's test. ***, **, *, ns: Significance at $\mathrm{P}<0.001,0.01,0.05$, not significant

\subsection{Texture evolution}

A significant decrease in firmness during storage was registered with the puncture test (Table 4). A higher firmness loss was detected after the MS period following each CS. Different authors reported the firmness evolution of peach fruit during storage (ROBERTSON et al., 1990; Dalla VAlle et al., 2007; Di VAio et al., 2008), but they used, in most cases, hand portable penetrometers, and registered only the yield point, thus our data provide more precise and objective information. The texture analysis well discriminated the peaches ripening stages.

\subsection{Colour, $I_{\mathrm{AD}}$, frost injury incidence, and moulds}

The parameters $a^{*}$ and $b^{*}$ changed significantly during storage (Table 5). In particular, $a^{*}$ increased after 14 days of CS, while $b^{*}$ changed only at 21 days of CS. These changes showed a deepening of the saturation of the colour, as demonstrated by the increase in the Chroma value. I peaches were lighter, more yellow, and with a higher saturation than CM fruit, and with a lower hue value. Only the a* parameter was not affected by the ripening stage. Thus, CIELAB parameters may be suggested to follow the evolution of ripening of the red skin peach cultivars, but the $\mathrm{I}_{\mathrm{AD}}$ values give the best results as a level of significance higher than 0.001 was registered for the decrease in $\mathrm{I}_{\mathrm{AD}}$ values during storage and for differences in the ripening stage, as already reported in the literature (RUIZ-Altisent et al., 2006; Ziosi et al., 2008; BonORA et al., 2013). 


\begin{tabular}{lccc}
\multicolumn{4}{c}{ Table 4. Influence of storage time and ripening stage on texture parameters of peach fruit } \\
\hline Source & & Puncture indices & Gradient \\
\cline { 2 - 4 } & & Area & $\left(\mathrm{N} \mathrm{s} \mathrm{s}^{-1}\right)$ \\
\hline Storage time (days) & & & $9.4 \mathrm{a}$ \\
0 & $39.1 \mathrm{a}$ & $84.7 \mathrm{a}$ & $5.4 \mathrm{c}$ \\
$0+3$ & $27.7 \mathrm{c}$ & $72.4 \mathrm{~b}$ & $8.7 \mathrm{a}$ \\
7 & $37.1 \mathrm{ab}$ & $82.2 \mathrm{ab}$ & $1.5 \mathrm{e}$ \\
$7+3$ & $7.7 \mathrm{e}$ & $23.7 \mathrm{~d}$ & $1.2 \mathrm{e}$ \\
14 & $34.1 \mathrm{~b}$ & $83.3 \mathrm{ab}$ & $1.2 \mathrm{e}$ \\
$14+3$ & $3.8 \mathrm{f}$ & $7.9 \mathrm{e}$ & $3.5 \mathrm{~d}$ \\
21 & $15.0 \mathrm{~d}$ & $37.2 \mathrm{c}$ & $1.2 \mathrm{e}$ \\
$21+3$ & $3.3 \mathrm{f}$ & $5.9 \mathrm{e}$ & $* * *$ \\
Significance & $* * *$ & $* * *$ & \\
Ripening stage $\left(\mathrm{I}_{\mathrm{AD}}\right)$ & & & $4.1 \mathrm{~b}$ \\
CM & & & $5.4 \mathrm{a}$ \\
I & $17.6 \mathrm{~b}$ & $41.7 \mathrm{~b}$ & $* *$ \\
Significance & $24.7 \mathrm{a}$ & $57.7 \mathrm{a}$ & $* * *$ \\
\hline
\end{tabular}

Data followed by different letters for each source and column are significantly different by Tukey's test. ***: Significance at $\mathrm{P}<0.001$

Table 5. Influence of storage time and ripening stage on colour and ripening stage $\left(\mathrm{I}_{\mathrm{AD}}\right)$ of peach fruit

\begin{tabular}{|c|c|c|c|c|c|c|}
\hline $\begin{array}{l}\text { Source of } \\
\text { variation }\end{array}$ & $\mathrm{L}$ & $\mathrm{a}^{*}$ & $\mathrm{~b}^{*}$ & $\begin{array}{c}\text { Hue } \\
\left(1 / \tan b^{*} / a^{*}\right)\end{array}$ & $\begin{array}{l}\text { Chroma } \\
\left(\mathrm{a}^{2}+\mathrm{b}^{2}\right)^{0.5}\end{array}$ & $\mathrm{I}_{\mathrm{AD}}$ \\
\hline \multicolumn{7}{|c|}{ Storage time (days) } \\
\hline 0 & $38.0 \mathrm{a}^{\mathrm{x}}$ & $23.2 \mathrm{c}$ & $15.8 b$ & $56.9 \mathrm{a}$ & $28.6 \mathrm{c}$ & $1.04 \mathrm{a}$ \\
\hline $0+3$ & $35.9 \mathrm{a}$ & $26.9 b$ & $17.3 \mathrm{ab}$ & $58.2 \mathrm{a}$ & $32.3 \mathrm{bc}$ & $0.85 b$ \\
\hline 7 & $35.1 \mathrm{a}$ & $25.9 \mathrm{bc}$ & $16.1 \mathrm{~b}$ & $59.1 \mathrm{a}$ & $30.7 \mathrm{bc}$ & $0.91 b$ \\
\hline $7+3$ & $38.2 \mathrm{a}$ & $26.0 \mathrm{bc}$ & $16.7 \mathrm{~b}$ & $57.5 \mathrm{a}$ & $31.3 \mathrm{bc}$ & $0.55 \mathrm{~d}$ \\
\hline 14 & $35.4 \mathrm{a}$ & $28.0 \mathrm{ab}$ & $18.4 \mathrm{ab}$ & $57.9 \mathrm{a}$ & $34.0 \mathrm{ab}$ & $0.72 \mathrm{c}$ \\
\hline $14+3$ & $37.4 \mathrm{a}$ & $28.1 \mathrm{ab}$ & $16.1 \mathrm{~b}$ & $60.8 \mathrm{a}$ & $32.6 \mathrm{bc}$ & $0.37 \mathrm{ef}$ \\
\hline 21 & $37.9 \mathrm{a}$ & $30.2 \mathrm{a}$ & $20.6 \mathrm{a}$ & $57.2 \mathrm{a}$ & $37.0 \mathrm{a}$ & $0.47 \mathrm{de}$ \\
\hline $21+3$ & $36.0 \mathrm{a}$ & $27.1 \mathrm{~b}$ & $17.9 \mathrm{ab}$ & $57.7 \mathrm{a}$ & $32.8 b$ & $0.28 \mathrm{f}$ \\
\hline Significance & ns & $* * *$ & $* *$ & $\mathrm{~ns}$ & $* * *$ & $* * *$ \\
\hline \multicolumn{7}{|c|}{ Ripening stage $\left(\mathrm{I}_{\mathrm{AD}}\right)$} \\
\hline $\mathrm{CM}$ & $35.3 b$ & $26.8 \mathrm{a}$ & $15.4 \mathrm{~b}$ & $60.8 \mathrm{a}$ & $31.2 b$ & $0.53 b$ \\
\hline I & $38.2 \mathrm{a}$ & $27.1 \mathrm{a}$ & $19.3 \mathrm{a}$ & $55.5 \mathrm{~b}$ & $33.7 \mathrm{a}$ & $0.77 \mathrm{a}$ \\
\hline Significance & $* * *$ & ns & $* * *$ & $* * *$ & $* * *$ & $* * *$ \\
\hline
\end{tabular}

Data followed by different letters for each source and column are significantly different by Tukey's test. $* * *, * *$, ns: Significance at $\mathrm{P}<0.001,0.01$, not significant

Peaches did not evidence frost injury symptoms, although they were stored at a temperature falling in the so-called "killing temperature zone". No mould growth was detected. 


\section{Conclusions}

The results of our study revealed that only some parameters can be used to follow adequately the evolution of ripening of peach fruit harvested at immature and commercial mature stages during CS and MS. In fact, out of weight loss, only firmness and $\mathrm{I}_{\mathrm{AD}}$ changed significantly during CS followed by MS, with respect to the correspondent CS. These parameters were also useful in discriminating the ripening stages of peaches, along with some minor acids, sucrose, and TA to TS ratio. In vitro AA increased significantly during the storage period, although amounts of major responsible compounds, polyphenols and ascorbic acid, did not change during the whole time. CM fruit, moreover, had a higher AA, compared to I peaches, while the latter showed a more equilibrated ratio of TS/TA.

The paper was financially supported by University of Sassari, project FAR2011 "Studio della componente polifenolica e delle proprietà antiossidanti di due varietà di pesche raccolte a differenti stadi di maturazione". The authors thank Agris Sardegna, Dipartimento per la Ricerca nell'Arboricoltura, Servizio Arboricoltura, for kindly providing the DA-meter instrument.

\section{References}

Bassi, D. \& Selli, R. (1990): Evaluation of fruit quality in peach and apricot. Adv. Hortic. Sci., 4, $107-112$.

Bonora, E., Noferini, M., Vidoni, S. \& Costa, G. (2013): Modeling fruit ripening for improving peach homogeneity in planta. Sci. Hortic-Amsterdam, 159, 166-171.

Dagar, A., Weksler, A., Friedman, H. \& Lurie, S. (2012): Gibberellic acid (GA3) application at the end of pit ripening: effect on ripening and storage of two harvests of "September Snow" peach. Sci. Hortic-Amsterdam, $140,125-130$.

Dalla Valle, A.Z., Mignani, I., Spinardi, A., Galvano, F. \& Cappellano, S. (2007): The antioxidant profile of three different peaches cultivars (Prunus persica) and their short term effect on antioxidant status in human. Eur. Food Res. Technol., 225, 167-172.

Di Vaio, C., Graziani, G., Marra, L., Cascone A. \& Ritieni, A. (2008): Antioxidant capacities, carotenoids and polyphenols evaluation of fresh and refrigerated peach and nectarine cultivars from Italy. Eur. Food. Res. Technol., 227, 1225-1231.

Infante, R. (2012): Harvest maturity indicators in the stone fruit industry. Stewart Postharvest Rev., 8, 1-6.

McCune, L.M., Kubota, C., Stendell-Holllis, N.R. \& Thomson, C.A. (2010): Cherries and health: A review. Crit. Rev. Food Sci. Nutr., 51(1), 1-12.

Orazem, P., Stampar, F. \& Hudina, M. (2011): Fruit quality of Redhaven and Royal Glory peach cultivars on seven different rootstocks. J. Agr. Food Chem., 59, 9394-9401.

Piga, A., Del Caro, A. \& Corda, G. (2003): From plums to prunes: influence of drying parameters on polyphenols and antioxidant activity. J. Agr. Food Chem., 51, 3675-3681.

Robertson, J.A., Meredith, F.I., Horvat, R.J. \& Senter, S.D. (1990): Effect of cold storage and maturity on the physical and chemical characteristics and volatile constituents of peaches (Cv. Cresthaven). J. Agr. Food Chem., 38, 620-624.

Ruiz-Altisent, M., Lleó, L. \& Riquelme, F. (2006): Instrumental quality assessment of peaches: Fusion of optical and mechanical parameters. J. Food Eng., 74, 490-499.

Singleton, V.L. \& Rossi, J.A. JR (1965): Colorimetry of total phenolics with phosphomolybdic-phosphotungstic acid reagents. Am. J. Enol. Viticult., 16, 144-158.

Tomas-Barberan, F.A., Gil, M.I., Cremin, P., Waterhouse, A.L., Hess-Pierce, B. \& Kader, A.A. (2001): HPlCDAD-ESIMS analysis of phenolic compounds in nectarines, peaches, and plums. J. Agr. Food Chem., 49, 4748-4760.

Vicente, A.R., Manganaris, G.A., Cisneros-Zevallos, L. \& Chrisosto, C.H. (2011): Prunus. -in: Terry, L. (Ed.), Health-promoting properties of fruit and vegetables. Cabi, Wallingford, UK., pp. 238-259.

Ziosi, V., Noferini, M., Fiori, G., Tadiello, A., Trainotti, L., Casadoro, G. \& Costa, G. (2008): A new index based on vis spectroscopy to characterize the progression of ripening in peach fruit. Postharvest Biol. Tec., 49, 319-329. 